\title{
Ambient Air Quality Monitoring and Management in Moradabad
}

\author{
${ }^{a}$ Raina Pal, ${ }^{a}$ Mahima, ${ }^{a}$ Anshuman Gupta and ${ }^{\mathrm{a} *}$ Anamika Tripathi \\ ${ }^{a}$ Department of Botany, Hindu College, Moradabad, India 244001
}

\begin{abstract}
The present study deals with the assessment of ambient air quality with respect to Total Suspended Particulates (TSP), Respirable Suspended Particulate Matter $\left(\mathrm{PM}_{10}\right)$, Sulphur dioxide $\left(\mathrm{SO}_{2}\right)$ and Nitrogen dioxide $\left(\mathrm{NO}_{2}\right)$ considered over a period of two years from Sep 2010 to Aug. 2012. Air quality index are used for local and regional air quality management in many cities of the world. The air quality index has been determined at three different sites i.e. PTC (SI), Buddh Bazar (SII) and Mughalpura (SIII) of Moradabad city. The experimental results obtained from the different air quality categories according to national ambient air quality standard at different site as PTC (SI) though looks a clean area, falls under moderate pollution category with 68.78 index value. This may be due to fossil fuel combustion at the outskirts of the parade grounds and burning of dry leaves inside the area. Buddh Bazar (SII) which is a commercial area falls under high air pollution category with 99.48 index value. This site near railway station is extremely congested resulting in slow movement of vehicles, long waits at the signals and a large number of vehicles running during the day and night time. Mughalpura (SIII) is an industrial area, falls under the very high pollution category with 120.99 index value, may be due to the industrial activities i.e. mainly brasswares. Five heavy metals i.e. $\mathrm{Cu}, \mathrm{Zn}, \mathrm{Fe}, \mathrm{Cd}$ and $\mathrm{Pb}$ were also observed at all the sites. Among the metals highest concentration of $\mathrm{Zn}$ was recorded at almost all the sites whereas $\mathrm{Cu}, \mathrm{Zn}$ and $\mathrm{Fe}$ was found higher at industrial site, may be attributed to melting of Brass sillies to prepare the different Brassware items.
\end{abstract}

Keywords: AQI, Heavy Metals, Air Quality Management

\section{Introduction}

Exposure to air pollution is the main environmental threat to human health and vegetation. Various chemicals are being emitted into the air from both, natural and anthropogenic sources. In spite of the introduction of cleaner technologies in industry, energy production and transport, air pollution remains a major health risk.

Particulate matter pollution is nowadays one of the most concerning problems in urban cities, not only because of the adverse health effects, but also for the reducing atmospheric visibility and affect to the state of conversion of various cultural heritages [1]. A number of epidemiological studies [24] have demonstrated that acute and chronic health effects are related to the inhalable $\mathrm{PM}_{10}$ exposure in the urban environment may be due to the carriers of acidic or toxic species, and some data also seem to indicate possible seasonal effects of the particulate matter on human health. Scientists have argued that $\mathrm{PM}_{10}$ could be substituted as a better standard cut-off point or more effective indicator for fine particles rather than $\mathrm{PM}_{2.5}$ [5] because human respiratory systems are highly associated with $\mathrm{PM}_{10}$ levels $[6,2]$. Besides particulate matter, literature also suggests that there is a strong relationship between higher concentration of $\mathrm{SO}_{2}$ and $\mathrm{NO}_{2}$ and several health effects [7], like cardiovascular diseases [8, 9], respiratory health effects such as asthma and bronchitis [10], reproductive and developmental effects such as increased risk of preterm birth [11].

\begin{abstract}
Among all other pollutants, air borne trace elements are a major threat to the human health [12]. Normally toxic trace elements are found to be associated with the finer particle size rather than coarser ones [13]. Heavy metals present in suspended PM are considered to be a health hazard since they are readily absorbed by the lung tissues. Toxicological in vitro and in vivo studies have shown that metals are harmful components of PM as they can cause different cardiovascular and lung diseases [14].
\end{abstract}

The AQI (Air Quality Index) for the pollutants is an index to indicate and to monitor trends of the medium and long term back- ground pollution levels that are typically higher in urban areas than in rural setting and this is largely due to the 
concentration of human activities that occur in cities [15]. Already Environmental Protection Agency (EPA) is using the AQI for the following five major pollutants regulated by clean air viz. ground level ozone, particulate matter, carbon monoxide, sulphur dioxide and nitrogen dioxide. For each of these pollutants EPA has set National Ambient Air Quality Standards (NAAQS) to protest against harmful health effects.

The present study was undertaken to estimate the level of criteria pollutants and trace metal accumulation $(\mathrm{Cu}, \mathrm{Zn}, \mathrm{Fe}$, $\mathrm{Cd}$ and $\mathrm{Pb}$ ) in atmospheric environment of Moradabad city for the period of two years. The air quality index is estimated for respective areas, i.e. residential, commercial and industrial. A detailed environmental management plan for Moradabad city is also discussed herewith.

\section{Material and Methods 2.1. Study Area}

Moradabad is the Brasscity of India, situated in northern India with a population of 889,810 (Census, 2011) and lies between $28^{0} 15^{\prime}$ Latitude and $74^{0} 49$ Longitude at $76.19 \mathrm{~m}$ above sea level. Monitoring of SPM, $\mathrm{PM}_{10}, \mathrm{SO}_{2}$ and $\mathrm{NO}_{2}$ was done simultaneously in the ambient air at three different locations of Moradabad city. As seen in Fig. 1. sampling locations in Moradabad include Police Training Centre (PTC, SI) Buddh Bazar (SII) and Mughalpura (SIII) representing residential, commercial and industrial area respectively.

Moradabad is famous worldwide for brassware. It is the largest producing and exporting centre of Brass items. In and around the city there are about 7137 small and large industries are located and about 36,915 workers are working in these industries (Industries Directory 2012). The vehicular population in the city is increasing day by day. About 44039 vehicles were recorded in Moradabad up to March 2012 (RTO, Moradabad). The brassware industries and the increasing number of vehicles are degrading the air quality of Moradabad city.

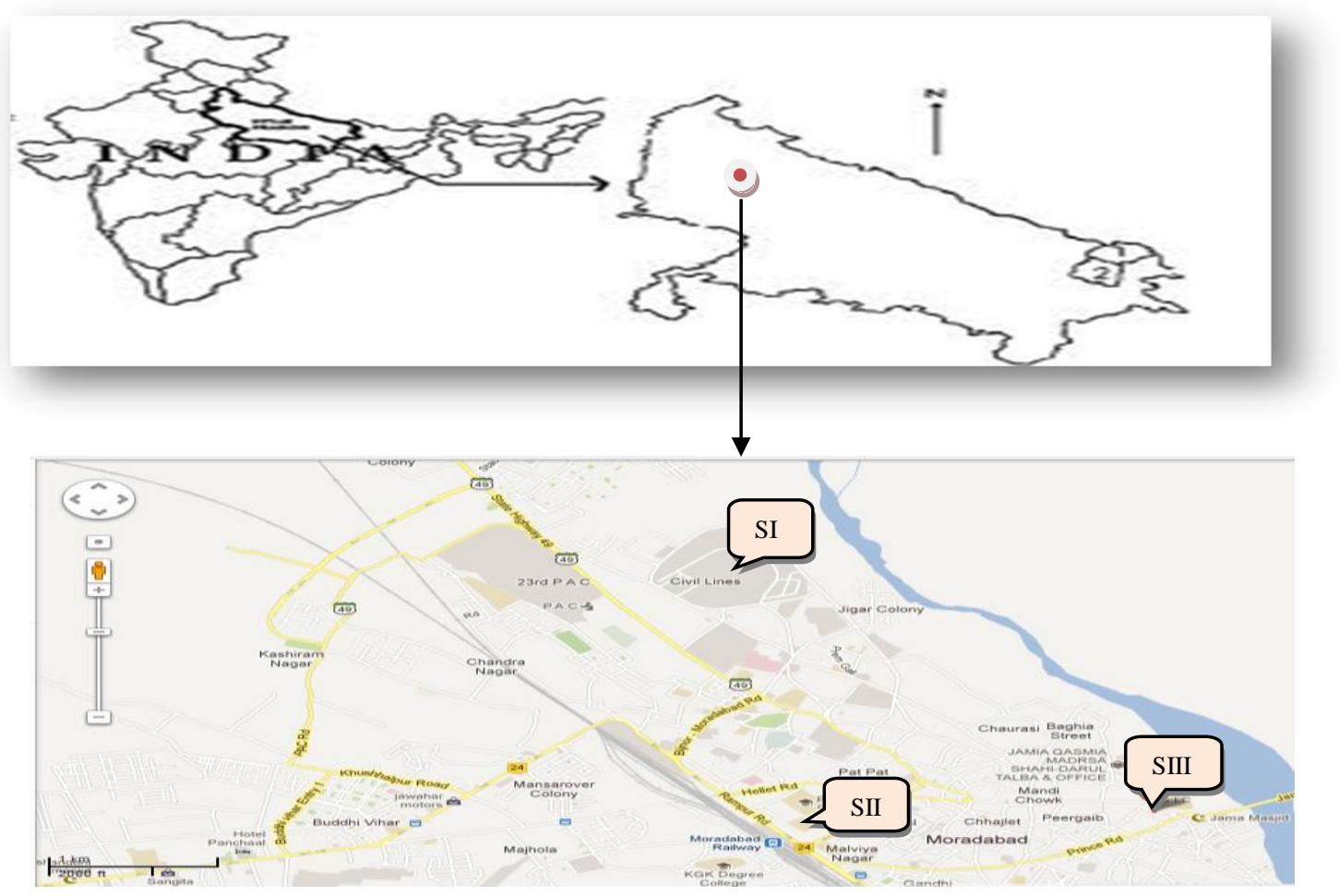

Fig. 1. Map of the sampling site

\subsection{Sampling and Analysis}

Monitoring of SPM and $\mathrm{PM}_{10}$ was carried out using Respirable Dust Sampler (Model-460NL, Envirotech, New Delhi) at a flow rate of $1.0-1.2 \mathrm{~m} 3 / \mathrm{min}$ for two samples per week on Whatman glass fiber filter paper - GF/A for 24 hrs. (Three shift, i.e. $8 \mathrm{hrs}$ ). The difference in initial and final weight of the filter paper gave the total quantity of RSPM collected over the 24 hours period. The values of $\mathrm{PM}_{10}$ were reported in $\mu \mathrm{g} / \mathrm{m}^{3}$.

react with para rosaniline and methysulphonic acid. The absorbance of the solution was measured at a wavelength of
Mass concentration of SPM was calculated by adding the concentration of RSPM and NRPM (as the air with suspended particulates enters the cyclone, coarse non-respirable dust is separated from the air stream by centrifugal forces. The suspended particulate matter falls through the cyclone's conical hopper and is collected in the cyclonic-cup).

The analysis of $\mathrm{SO}_{2}$ and $\mathrm{NO}_{2}$ was done by Bureau of Indian Standard (BIS) methods [16, 17]. A known quantity was passed through the impinger containing known volume of absorbing solution: $\mathrm{SO}_{2}$ is absorbed in absorbing solution, sodium tetrachloromercurate dichlorsulphitomercurate complex is formed which made to

$560 \mathrm{~nm}$ on spectrophotometer (Systronics 166). Whereas, Nitrogen oxides (NOx) as nitrogen dioxide was observed in 
absorbing solution, sodium hydroxide which formed a stable solution of sodium nitrite. The nitrite ion produced was determined colorimetrically at a wavelength $540 \mathrm{~nm}$ by reacting the exposed absorbing reagent with phosphoric acid, sulphanilamide and $\mathrm{N}$ (1- naphthyl) ethylenediamine dihydrochloride.

\subsection{Heavy Metal / Elemental Analysis}

For heavy metal analysis, a portion of the fiber filter paper covered by particulates was digested by nitric acid and perchloric acid at $140^{\circ} \mathrm{C}$ hot plate. Residues were then redissolved by $0.1 \mathrm{~m}$ hydrochloric acid and a blank was also prepared using the same area of unexposed glass fiber filter paper and by treating the same procedure. These were cooled, filtered and made to $50 \mathrm{ml}$ by distilled water. Concentrations of heavy metals were analyzed by Inductively Coupled PlasmaOptical Emission Spectrophotometer (ICP-OES; Spectro Analytical Instruments, West Midlands, UK) from samples collected for each site.

\subsection{Statistical Analysis}

Summary statistics were used to obtain the means and standard deviations for the criteria pollutants and trace metals. One-way analysis of variance (ANOVA) was applied to detect the significant difference between metals and within metals ( $p$ $\leq 0.01)$.

\section{Results and Discussion}

\subsection{Air Quality Status and Trend}

The air quality data of selected parameters from three different monitoring stations have been analyzed to determine the status and trend in the ambient air during the period of September 2010 to August 2012. It has been found that annual average concentrations of $\mathrm{PM}_{10}$ and Total Suspended Particulate Matter are found to exceed the National Standards (NAAQS) while the annual average of sulphur dioxide and nitrogen dioxide were found to be within the national standards [19]. The Central Pollution Control Board (CPCB), New Delhi has presented a maximum permissible limit for each air pollutant for specific areas.

\subsubsection{Particulate Matter (PM $M_{10}$ and TSP)}

There is now growing concern all over the world about particulate matter of size 10 micron and 2.5 micron $\left(\mathrm{PM}_{10}\right.$ and ${ }_{2.5}$ ) or less. The WHO has classified these as thoracic particles because they are respirable and because of their small size get lodged deep down in the lower respiratory track. These particles exacerbate cardiac and respiratory problems among the primary pollutants [18]. Results show that the annual mean concentrations of $\mathrm{PM}_{10}$ at different sites in Moradabad city, i.e. PTC (residential area, SI), Buddh Bazar (commercial area, SII) and Mughalpura (industrial area, SIII) were $130.91 \mu \mathrm{g} / \mathrm{m}^{3}$, $178.04 \mu \mathrm{g} / \mathrm{m}^{3}, 181.45 \mu \mathrm{g} / \mathrm{m}^{3}$ respectively which are more than the permissible limit of NAAQS [19].

The monthly mean concentrations of $\mathrm{PM}_{10}$ ranged between 45 $290 \mu \mathrm{g} / \mathrm{m}^{3}$ during the period of Sep. 2010-Aug. 2012. The highest monthly mean concentration was observed at Mughalpura in the month of January 2011, while the lowest concentration was found at PTC in the month of September
2010. All the mean monthly values were found to exceed the national standard at each site except at PTC (SI) in the month of September (Fig. 2a).

The annual concentrations of TSP at all the sites were found $141.91 \mu \mathrm{g} / \mathrm{m}^{3}$ (SI), $299.95 \mu \mathrm{g} / \mathrm{m}^{3}$ (SII), $327 \mu \mathrm{g} / \mathrm{m}^{3}$ (SII) respectively. At all the respective sites the annual concentrations crossed the prescribed annual limit [19]. The monthly mean concentrations of Total Suspended Particulates ranged between $88-431 \mu \mathrm{g} / \mathrm{m}^{3}$. The maximum concentration was recorded at Mughalpura in December 2010, while the lowest concentration was found at PTC in August 2011. At commercial (SII) and industrial (SIII) sites, all the mean monthly values exceeded the prescribed the NAAQS while at residential (SI) site some values were within the prescribed limit (Fig. 2b).

According to Fig. 2a and 2b, the concentrations of particulate pollutants were found to be highest in winter season and lowest in monsoon season. The foggy hazy conditions are said to have been caused by persistent particulate emissions from air pollution sources in association with a proglonged dry period in stable meteorological conditions [20]. This creates an unfaurable conditions for efficient transportation and dispersion of surface pollutants in the region.

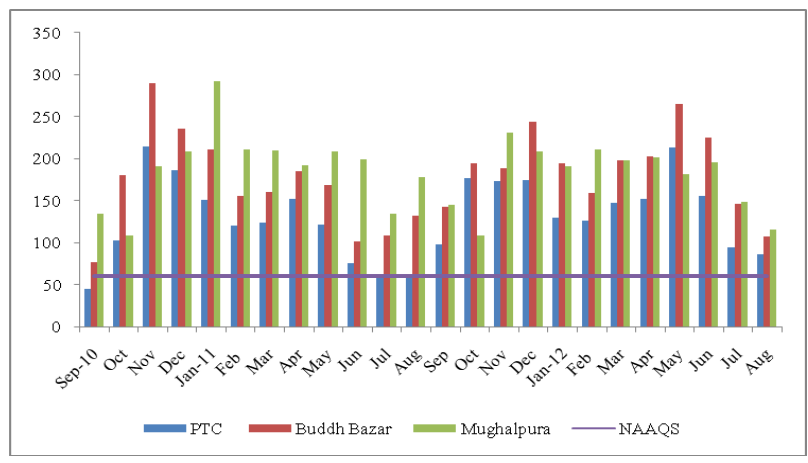

Fig. 2a. Status and trend of $\mathrm{PM}_{10}\left(\mu \mathrm{g} / \mathrm{m}^{3}\right)$ at three sites of Moradabad

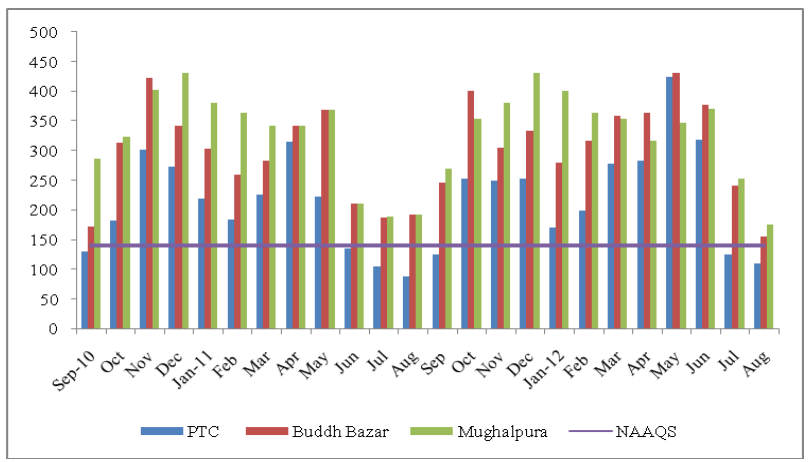

Fig. 2b. Status and trend of TSP $\left(\mu \mathrm{g} / \mathrm{m}^{3}\right)$ at three sites of Moradabad city

\subsubsection{Gaseous Pollutants ( $\mathrm{SO}_{2}$ and $\left.\mathrm{NO}_{2}\right)$}

Results for the gaseous concentrations were presented in Fig. $3 \mathrm{a}$ and $3 \mathrm{~b}$. The annual mean concentration of sulphur dioxide for three respective site, i.e. SI (residential), SII (commercial) 
and SIII (industrial), were found $10.75 \mu \mathrm{g} / \mathrm{m}^{3}, 12.91 \mu \mathrm{g} / \mathrm{m}^{3}$, $19.87 \mu \mathrm{g} / \mathrm{m}^{3}$ respectively. The annual concentration of $\mathrm{SO}_{2}$ at all the representative sites are not more than the prescribed limit of NAAQS, i.e. $50 \mu \mathrm{g} / \mathrm{m}^{3}$. The monthly mean concentrations of $\mathrm{SO}_{2}$ ranged between $5-25 \mu \mathrm{g} / \mathrm{m}^{3}$ during the study period. The highest monthly mean concentration was recorded at Mughalpura in January 2011, while the minimum mean concentration was found at PTC in the month of September 2010. High level of $\mathrm{SO}_{2}$ are particularly dangerous in the presence of PM, because it slowly absorbs on fine atmospheric particles and can be transported very deep into the lungs causing damage to the lung tissues. The monthly mean concentrations at all the sites, i.e. residential, commercial and industrial, were within the recommended standard of NAAQS (Fig. 3a)

$\mathrm{NO}_{2}$, which is generated maximaly due to the vehicles, was recorded annualy $18.83,25.28$ and $30.54 \mu \mathrm{g} / \mathrm{m}^{3}$ at PTC (SI), Buddh Bazar (SII) and Mughalpura (SIII) respectively.

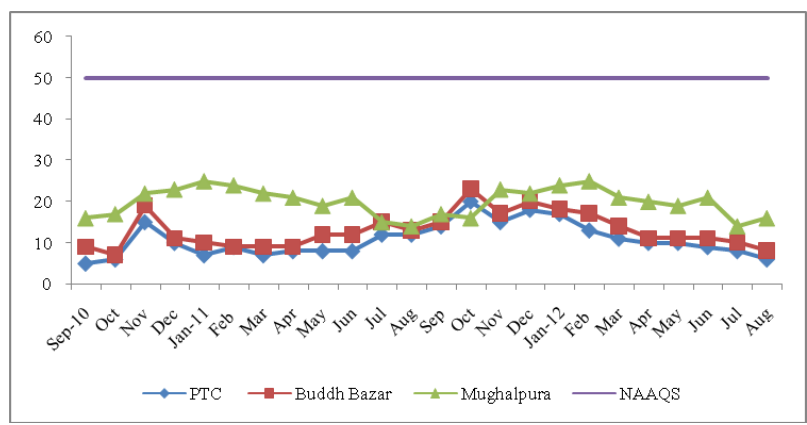

Fig. 3a. Status and trend of $\mathrm{SO}_{2}\left(\mu \mathrm{g} / \mathrm{m}^{3}\right)$ at three sites of Moradabad city

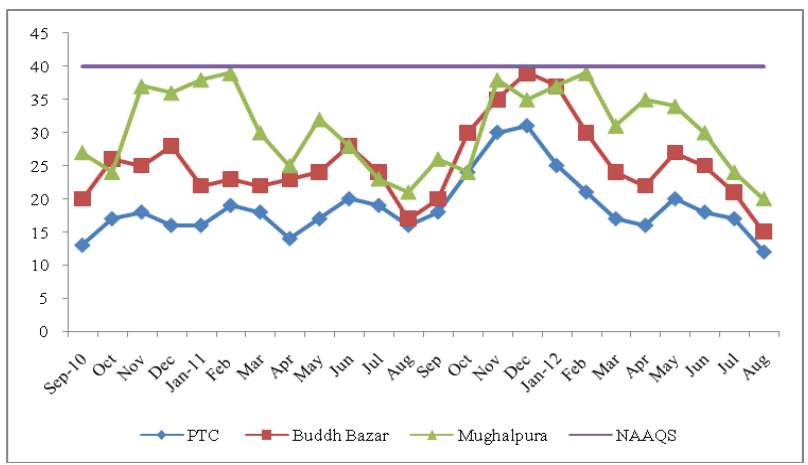

Fig. 3b. Status and trend of $\mathrm{NO}_{2}\left(\mu \mathrm{g} / \mathrm{m}^{3}\right)$ at three sites of Moradabad city
These values did not exceed the prescribed limit [19]. According to the Fig. $3 \mathrm{~b}$ the monthly mean concentration ranged between $12-39 \mu \mathrm{g} / \mathrm{m}^{3}$. The minimum concentration was recorded in the month of August 2012 in residential area, while the maximum concentration was found in the month of December 2011 in commercial area of the city. Buddh Bazar, a commercial site have a very congested and busy roads with an intensive transport activities, while the Police Training Centre (PTC), a residential site has an open space and greenery all around. The values of $\mathrm{NO}_{2}$ do not exceed the NAAQS. Maximum values are recorded in winter season, while the minimum concentration was recorded in monsoon. High values of gaseous pollutants in peak months of winter season may be attributed to inversion effect [21].

\subsection{Status of elemental concentration in ambient air}

Elements are the main constitution of PM that are toxic to human health, as well as plants and other species. The results for the elements are presented in Table 1 and 2. Among all the elements $(\mathrm{Cu}, \mathrm{Zn}, \mathrm{Fe}, \mathrm{Cd}$ and $\mathrm{Pb}) \mathrm{Zn}$ contributed the maximum concentration with an average of $11.96 \mu \mathrm{g} / \mathrm{m}^{3}$ followed by $\mathrm{Fe}$ $9.6 \mu \mathrm{g} / \mathrm{m}^{3}, \mathrm{Cu} 7.60 \mu \mathrm{g} / \mathrm{m}^{3}, \mathrm{~Pb} 1.94 \mu \mathrm{g} / \mathrm{m}^{3}, \mathrm{Cd} 0.10 \mu \mathrm{g} / \mathrm{m}^{3}$. The highest mean concentration of $\mathrm{Zn}\left(21.24 \pm 8.02 \mu \mathrm{g} / \mathrm{m}^{3}\right), \mathrm{Fe}$ $\left(18.4 \pm 1.83 \mu \mathrm{g} / \mathrm{m}^{3}\right)$, and $\mathrm{Cu}\left(15.12 \pm 9.16 \mu \mathrm{g} / \mathrm{m}^{3}\right)$ was found at site III while the concentration of $\mathrm{Pb}\left(2.72 \pm 1.22 \mu \mathrm{g} / \mathrm{m}^{3}\right)$ and $\mathrm{Cd}$ $\left(0.2 \pm 0.21 \mu \mathrm{g} / \mathrm{m}^{3}\right)$ was recorded at Site II (Table 1).

A number of brass industries are located in Mughalpura, the industrial area of the city, which are specialized in melting, casting, cutting, grinding, scraping, polishing, etc. During the process of melting and casting, a large amount of metal fumes are emitted, which may act as a sensitizer and cause allergies i.e. Asthma, Dermatitis, Bronchitis and Cancer etc [22, 23]. In these industries, Brass $(60 \% \mathrm{Cu}$ and $40 \% \mathrm{Zn})$ and German silver $(55 \% \mathrm{Cu}, 35 \% \mathrm{Zn}$ and $10 \% \mathrm{Ni})$ are the main alloys used for moulding purposes in making brassware items and other utensils in Moradabad.

It has been estimated that vehicular pollution is the primary cause of air pollution in the urban areas $(60 \%)$, followed by industries $(20-30 \%)$ in India [24, 25]. The vehicular population in Moradabad city has increased many folds. The major source of human lead accumulation in developing countries was found to be airborne lead and 90 percent of which comes from leaded gasoline [26]. Cadmium, one of the most dangerous pollutants for organism, is mainly derived from combustion of accumulators and carburetors of vehicles [27]. Vehicular traffic, which is a great source of the fine particulates, is often enriched in potentially toxic trace elements in the urban environment [28-30].

Table 1. Elemental status $\left(\mu \mathrm{g} / \mathrm{m}^{3}\right)$ in $\mathbf{P M}_{10}$ collected at three sites in Moradabad

\begin{tabular}{|c|c|c|c|c|c|c|c|c|c|c|c|c|}
\hline & \multicolumn{2}{|c|}{ PTC (SI) } & \multicolumn{6}{|c|}{ Buddh Bazar (SII) } & \multicolumn{2}{|c|}{ Mughalpura (SIII) } & \multirow[b]{2}{*}{ Avg } & \multirow[b]{2}{*}{ SD } \\
\hline & Min & $\operatorname{Max}$ & Avg & SD & Min & $\operatorname{Max}$ & Avg & SD & Min & $\operatorname{Max}$ & & \\
\hline $\mathrm{Cu}$ & 1.47 & 3.87 & 2.1 & 0.84 & 3.65 & 8.54 & 5.6 & 1.48 & 4.9 & 40.92 & 15.12 & 9.16 \\
\hline Zn & 0.8 & 2.8 & 2.5 & 0.72 & 5.02 & 21.09 & 12.2 & 4.76 & 8.97 & 21.94 & 21.24 & 8.02 \\
\hline $\mathrm{Fe}$ & 1.71 & 8.87 & 3.9 & 1.9 & 2.15 & 9.04 & 6.55 & 2.18 & 15.33 & 36.8 & 18.4 & 1.83 \\
\hline $\mathrm{Cd}$ & 0.0001 & 0.01 & 0.001 & 0.002 & 0.008 & 0.4 & 0.2 & 0.21 & 0.001 & 0.5 & 0.101 & 0.15 \\
\hline $\mathrm{Pb}$ & 0.56 & 1.23 & 1.01 & 0.36 & 1.72 & 5.9 & 2.72 & 1.22 & 1.13 & 4.03 & 2.1 & 0.77 \\
\hline
\end{tabular}




\begin{tabular}{|l|l|l|l|l|l|}
\hline \multicolumn{6}{|l|}{ Table 2 Correlation coefficient matrix (r) for selected elements in } \\
PM $_{\mathbf{1 0}}$ of three different sites \\
\hline & $\mathrm{Cu}$ & $\mathrm{Zn}$ & $\mathrm{Fe}$ & $\mathrm{Cd}$ & $\mathrm{Pb}$ \\
\hline $\mathrm{Cu}$ & 1 & & & & \\
\hline $\mathrm{Zn}$ & $\mathbf{0 . 7 0 8 9}$ & 1 & & & \\
\hline $\mathrm{Fe}$ & $\mathbf{0 . 6 7 9 1}$ & $\mathbf{0 . 6 9 2 3}$ & 1 & & \\
\hline $\mathrm{Cd}$ & 0.0876 & 0.3704 & 0.0426 & 1 & \\
\hline $\mathrm{Pb}$ & 0.1865 & 0.4161 & 0.2244 & $\mathbf{0 . 5 4 9 3}$ & 1 \\
\hline
\end{tabular}

was found between $\mathrm{Cu}-\mathrm{Zn}(\mathrm{r}=0.7089), \mathrm{Cu}-\mathrm{Fe}(\mathrm{r}=0.6791), \mathrm{Zn}$ $\mathrm{Fe}(\mathrm{r}=0.6923), \mathrm{Cd}-\mathrm{Pb}(\mathrm{r}=0.5493)$.

Based on the correlation study it may be concluded that the three metals viz. $\mathrm{Zn}, \mathrm{Fe}$ and $\mathrm{Cu}$ (Table 2) might be originated from similar sources [31], probably by the industrial emission or other anthropogenic activities.

A significant correlation was found between $\mathrm{Cd}-\mathrm{Pb}(\mathrm{r}=0.5493)$. These values are significant at $p \leq 0.001$ level. These elements are believed to be originated from automobile emissions together with industrial emissions, especially the metallurgical / electroplating units located in the industrial area of the city [32-33].

The correlation coefficient between five metals i.e. $\mathrm{Cu}, \mathrm{Zn}, \mathrm{Fe}$, $\mathrm{Cd}$ and $\mathrm{Pb}$ has been presented in Table 2. A strong correlation

Table 3 Air Quality Index and air quality category for three different sites of Moradabad city

\begin{tabular}{|c|c|c|c|c|c|c|}
\hline \multirow[t]{2}{*}{ Parameters / Sites } & \multicolumn{4}{|c|}{ Quality Rating } & \multirow[b]{2}{*}{ AQI } & \multirow[b]{2}{*}{ Category } \\
\hline & $\mathrm{SO}_{2}$ & $\mathrm{NO}_{2}$ & $\mathrm{PM}_{10}$ & TSP & & \\
\hline PTC (SI) & 22 & 47 & 218 & 101 & 68.78 & Moderate Air Pollution \\
\hline Buddh Bazar (SII) & 24 & 63 & 297 & 214 & 99.48 & High Air Pollution \\
\hline Mughalpura (SIII) & 40 & 76 & 302 & 234 & 120.9 & Very High Air Pollution \\
\hline
\end{tabular}

\subsection{Air Quality Assessment / Index}

The ambient Air Quality Index is an index for reporting the day to day air quality. It gives details about the cleanliness of ambient air to what extent ambient air is polluted. Indices of air pollution or air quality have been used for about 30 years. The following computation was used to derive the Air Quality Index of the sites under consideration.

$\mathrm{AQI}=1 / 4\left[\mathrm{TSP} / \mathrm{S} \mathrm{TSP}+\mathrm{PM}_{10} / \mathrm{PM}_{10}+\mathrm{SO}_{2} / \mathrm{SO}_{2}+\mathrm{NO}_{2} / \mathrm{S} \mathrm{NO} 2\right] \times 100$ Where ${ }_{\mathrm{S}} \mathrm{TSP},{ }_{\mathrm{S}} \mathrm{PM}_{10},{ }_{\mathrm{S}} \mathrm{SO}_{2},{ }_{\mathrm{S}} \mathrm{NO}_{2}$ represent the ambient air quality standard as prescribed by the CPCB for the respective pollutants and TSP, $\mathrm{PM}_{10}, \mathrm{SO}_{2}, \mathrm{NO}_{2}$ are the actual value of the pollutants.

The AQI scale was divided into six categories, each category describes the range of air quality and its associated potential health effect. From $0-25=$ clean air, 26-50= slight air pollution, $51-75=$ moderate air, $76-100=$ high air pollution, $101-125=$ very high air pollution, $>125=$ severe air pollution. PTC with index value $68.78 \mu \mathrm{g} / \mathrm{m}^{3}$ was categories under the moderate air pollution category. Buddh Bazar with index value 99.48 was found in the high pollution category while the Mughalpura with index value 120.9 was found in the category of very high air pollution (Table 3 ).

The results of air quality monitoring show that the pollution concentrations were highly variable at different sampling sites and depend on the active mobile and stationary pollutant emitting sources and its influence by the meteorological factors.

\subsection{Air Quality Management}

The objective of environmental management plan is first to estimate the quantum of the emission of major pollutants, i.e. $\mathrm{SO}_{2}, \mathrm{NO}_{2}, \mathrm{PM}_{10}$, TSP and Heavy Metals emitted from different sources and then to make recommendations on technological interventions for air pollution.

During this long term monitoring, the problem of air pollution is predominantly due to small/medium scale industries and vehicles. As the heavy industries are being shifted in outer areas, there are still a number of Brassware melting units in dense residential localities such as Mughalpura, causing respiratory illnesses. Emission from each small unit varies differently depending upon the fuel type used and metals melted. Thus each industry requires particular / specific attention towards air pollution control management.

Apart from industries, burning of e-waste further intensifies the air pollution problem of the city. E-waste (management and handling) rules 2012 that became effective last year is inadequate and does not clear much on the export and its import. E- waste is brought illegally in city from Delhi threw road. Pollution Control Board and city's Administration should cope up this problem at utmost priority.

As the number of vehicles have an exponential increase during recent years. Benzene, Toluene and VOC should also be in listed in NAMP Programme of Moradabad.

A rich Green Belt should be developed around the industries and should be of particularly mixed type plantation to support the biodiversity in Moradabad. The prevailing air pollution 
conditions should be identified. In order to select the plant suitable for pollution abatement, the appropriate selection is guided by their performance / response to pollution and also upon their economic /aesthetic value. Furthermore, the selected plant species should preferably be indigenous, fast growing, requiring minimal maintenance and self-rejuvenating.

Almost socio-economic activities i.e. construction of road, houses, industries, transport contribute to environmental degradation including air. These things provide a good life to residents of the city but at the same time these are responsible to degrade the quality of environment. Of course, now the city has to adopt the action plan based upon the air quality data trends and have also to become conscious of their environment.

\section{Conclusion}

This study concludes that the concentration of PM recorded at three different sites is more than the prescribed limit while gases are found within the prescribed limit recommended by the CPCB, MoEF. Air Quality Index reported in three different sites fall in the polluted category. The estimated airborne metal concentrations in $\mathrm{PM}_{10}$ were reported high and might be effected by three major sources i.e. industrial activities, traffic and illegal e-waste burning. These toxic emissions are associated with adverse health effect to the inhabitants as well as to the plants of the city. To develop strategy for air quality management of Moradabad city the first and foremost task is source identification, intensive monitoring data collection and diligent analyses.

\section{Acknowledgments}

The authors gratefully acknowledge the financial assistance provided by University Grant Commission, New Delhi and Central Pollution Control Board (CPCB), New Delhi, India. Thanks are also due to Mr. V. K. Rajput, Atul Kumar and Mahesh Kumar for their kind support in data sampling and analyses.

\section{References}

[1] Van Grieken R \& Delalieux F. X-ray spectrometry for air pollution and cultural heritage research. In: "Invited Lectures of the $5^{\text {th }}$ Gen. Conf. Balkan Phys. Union, BPU5", Eds., Serbian Physical Society, Belgrade, 2004: 234246.

[2] D. W. Dockery \& C. A. Pope III. Health effects of particulate air pollution: Lines that connect. J. Air \& Waste Manage Association 2006; 56: 709-742.

[3] H. R. Anderson, R. W. Atkinson, J. L. Peacock, M. J. Sweeting, L. Marston. Ambient particulate matter and health effects: publication bias in studies of short-term associations. Epidemiol. 2005; 16: 155-163, DOI: 10.1097/01.ede.0000152528.22746.0f

[4] A. Analitis, K. Katsouyanni, E. Dimakopoulou, A. K Samoli, Y. Nikoloulopoulos, G. Petasakis, J. Touloumi, H. Schwartz, H. R. Anderson, K. Cambra, F. Forastiere, D. Zmirou, J. M. Vonk, L. Clancy, B. Kriz, J. Bobvos, J. Pekkanen. Short-term effects of ambient particles on cardiovascular and respiratory mortality. Epidemiol. 2006; 17: 230-233, DOI: 10.1097/01.ede.0000199439.57655.6b
[5] N. Perez, J. Pey, X. Querol, A. Alastuey, J. M. Lopez and M. Viana. Partionating of Major and trace components in PM10 - PM2.5 - PM1 at an urban site in southern Europe. Atmos. Environ. 2008; 42: 1677-1691.

[6] T. F. Mar, T. V. Larson, R. A. Stier C. Claiborn and J. Q. Koenig. An analysis of the association between respiratory sytems in subjects with asthma and daily air pollution in Spoken, Washington. Inhal. Toxicol. 2004; 16: 809-815.

[7] L. Curtis, W. Rea, P. Smith-Willis, E. Fenyves \& Y. Pan. Adverse health effects of outdoor pollutants. Environmental International. 2006; 32: 815-830, http://dx.doi.org/10.1016/j.envint.2006.03.012

[8] A. Peters, S. Von Klot, M. Heier, I. Trentinaglia, A Horman, E. Wichmann et al. Exposure to traffic and the onset of myocardial infarction. New England Journal of Medicine. 2004; 351: 1721-1730.

[9] D. W. Dockery, H. Luttnabb-Gibson, D. Q. Rich, M. L. Link, M. A. Mittleman, D. R. Gold et al. Association of air pollution with increased incidence of ventricular tachyarrythmias recorded by implanted cardioverter defibrillators. Environmental Health Prespectives. 2005; 113: 670-674, DOI: 10.1289/ehp.7767

[10] A. G. Burnett, G. M. Williams, J. Schwartz, A. H. Nekker, T. L. Best, A. L. Prteiescgevsjt et al. Air Pollution and child respiratory health: A case-crossover study in Australia and New Zealand. American Journal of Respiratory and Critical Care Medicine. 2005; 171: 12721278 .

[11] S. Liu, D. Knewski, Y. Shi, Y. Chen and R. T. Burnett. Association between gaseous ambient air pollutants and adverse pregnancy outcomes in Vancouver, British Columbia. Environmental Health Prespectives. 2003; 111: 1773-1778.

[12] Xin Hu, Yun Zhang, Zhuheng Ding, Tijian Wang, Hongzhen Lian, Yuanyuan Sun, Jichun Wu: Bioaccessibility and health risk of arsenic and heavy metals $(\mathrm{Cd}, \mathrm{Co}, \mathrm{Cr}, \mathrm{Cu}, \mathrm{Ni}, \mathrm{Pb}, \mathrm{Zn}$ and $\mathrm{Mn})$ in TSP and $\mathrm{PM}_{25}$ in Nanjing, China. Atmos. Environ. 2012; 57: 143152.

[13] G. C. Fang C. N. Chang, Y. S. Wu, V. Wang, P. P. C. Fu, D. G. Yang, S. C. Chen and C. C. Chu. The study of fine and courser particles and metallic elements for the day time and night time in a suburban area of central Taiwan, Taichung. Chemosphere. 2000; 41: 639-644, 144.206.159.178/ft/166/20214/364644

[14] F. Dominici, R. D. Peng, L.B. Michelle et al. Fine particulate air pollution and hospital admission for cardiovascular and respiratory diseases. JAMA. 2006; 295: $1127-1134$

[15] K. George, A. Chaloulakou and P. A. Kassomenos. Development of an aggregate Air Quality Index of an urban Mediterranean agglomeration: Relations to potential health effects. Environ. Int. 2007; 33(5): 670-676, ISSN: 0160-4120

[16] Indian Standard. Methods for measurement of air pollution - Part VI: Nitrogen dioxide. IS 5182. Bureau of Indian Standard, New Delhi, 197. 
[17] Indian Standard. Methods for measurement of air pollution - Part 2: Sulphur dioxide. IS 5182. Bureau of Indian Standard, New Delhi, 2001.

[18] Urban air pollution in mega-cities of the world. World Health Organization and United Nations Environmental Programme. Blackwell Publishers, 108 Cowley Road, Oxford OX4 IJF Cambridge, UK. WHO/UNEP Report, 1992.

[19] NAAQS. The Gazette of India, Ministry of Environment and Forest, GOI, New Delhi, 2009.

[20] Sham S., Khean C.B., Peng L.C. and Fook L.S., The August 1990 haze in Malaysia with special reference to the Klang Valley region. Malaysia Meteorological Service, Technical Note No. 49; 1991.

[21] X. K. Wang, and W. Z. Lu. Seasonal variation of air pollution index :Hong Kong case study. Chemosphere. 2006; 63: 1261-1272, DOI 10.1016/j.chemosphere.2005.10.031

[22] V. C. Garcia, E. Gego, S. Lin, C. Pantea, K. Rappazzo, A. Wotten, S.T. Rao. An evaluation of transported pollution and respiratory related hospital admission in the state of New York. Atmos. Poll. Res. 2011; 2: 9-15, DOI: 10.5094/APR.2011.002

[23] B. Dubey, A.K. Pal, and G. Singh. Trace metal composition of air borne particulate matter in the coal mining and non mining areas of Dhanbad region, Jharkhand, India. Atmos. Poll. Res. 2012; 3: 238-246, DOI: 10.5094/APR.2012.026

[24] S. Greaves, T. Issarayangyun and Q. Liu. Exploring variability in pedestrian exposure to/ fine particulates $\left(\mathrm{PM}_{2.5}\right)$ along a busy road. Atmospheric Environment. 2008; 42: (8); 1665-1676, DOI: 10.1016/j.atmosenv.2007.11.043

[25] S. K. Prajapati, B.D. Tripathi and V. Pathak. Distribution of vehicular pollutants in street canyons of Varanasi, India: A different case. Environ. Monit. Assess. 2009; 148: $176-172$.

[26] MECA: The case for banning lead in Gasoline manufactures of emission controls association Washington DC, USA, 51: 2003.
[27] F. Drewnick, S. S. Hings, J. Curtius, G. Eerdekens, J. Williams. Measurement of fine particulate and gas-phase species during the New Year's fireworks 2005 in Mainz, Germany. Atmos. Environ. 2006; 40: 4316-4327, DOI: 10.1016/j.atmosenv.2006.03.040

[28] Z. Sher, and F. Hussain. Effect of automobile traffic on some cultivated trees along road side in Peshawer, Pakistan. Pak. J. Pl. Sci. 2006; 12: 47-54.

[29] A. Cicek, A. S. Koparal, A. Aslan, K. Yazici. Accumulation of heavy metals from motor vehicles in transplanted lichens in an urban area. Commun. Soil Sci. Plant Anal. 2008; 39: 168-176, DOI: $10.1080 / 00103620701759111$

[30] M. H. Shah, N. Shaheen, N. Rashida. Assessment of the trace elements level in urban atmospheric particulate matter and source apportionment in Islamabad, Pakistan. Atmos. Pollu. Res. 2012; 3: 39-45, DOI:10.5094/APR.2012.003

[31] D. K. A. Banarjee. Heavy metal levels and solid phase speciation in street dust of Delhi, India. Environ. Pollut. 2003; 123: 95-105, http://dx.doi.org/10.1016/S0269_ 7491(02)0037-8

[32] F. Zereini, F. Alt, J. Messerschmidt, C. Wiseman, I. Feldmann, A. Von Bohlen, J. Muller, K. Liebl, W. Puttmann. Concentration and distribution of heavy metals in urban airborne particulate matter in Frankfurt am Main, Germany. Environ. Sci. Technol. 2005; 39: 2983-2989.

[33] M. H. Shah, N. Shaheen. Annual and seasonal variations of trace metals in atmospheric suspended particulate matter in Islamabad, Pakistan. Water Air and Soil Pollut. 2008; 190: 13-25, ISSN: 0049-6979 